\title{
THE CONTINUATION OF COMMUNIST-ERA TOTALITARIAN POLICIES IN THE EUROPEAN UNION: THE CASE OF BULGARIA, THE MACEDONIAN MINORITY AND MACEDONIA'S EU INTEGRATION
}

\author{
Stojko STOJKOV ${ }^{1}$, \\ Goce Delčev University, Štip
}

\begin{abstract}
This article deals with the Bulgarian denial of the Macedonian minority in Bulgaria, which is a key moment in the Bulgarian veto against Macedonia's EU integration. The Bulgarian position that the Macedonian minority in Bulgaria does not exist directly contradicts the fact that this minority was previously officially recognized in Bulgaria and that in almost all censuses in the last 80 years thousands of Bulgarian citizens identified themselves as Macedonians. Refusing to face the reality and contrary to the recommendations of various international organizations and institutions in the last 20 years, the Bulgarian government refuses to start a dialogue with the minority and ascribes the actions of the Bulgarian citizens with Macedonian self-awareness to the R. Macedonia. However, initiatives in the international organizations and institutions in support of the Macedonian minority are not initiated by the Republic of Macedonia, but, quite the opposite, by Bulgarian citizens and organizations; such forums include not only the Council of Europe's system in Strasbourg and the UN, but also the institutions of the European Union, where in fact Macedonia is not a member. Formulated back in 1963, the policy of denial of the Macedonian minority was the first in a series of "revival processes" aimed at assimilating minorities into a "unified Bulgarian socialist nation", but at the same time it is the last process to remain not condemned in Bulgaria and that continues to be implemented even today. During the communist era, this policy resulted in the deportation of a few thousand people to prisons, camps, or internments, as well as in the implementation of many other forms of repression. After the fall of communism, it resulted in exactly 14 judgments against Bulgaria ruled by the Strasbourg based European Court of Human Rights. The policy of the Bulgarian state today, which in essence follows the line created by the late dictator Todor Zhivkov, is the last totalitarian communist policy in the European Union.
\end{abstract}

Keywords: Macedonian minority, Bulgaria, EU, integration, minority rights

\section{Introduction}

After the signing of the Joint Declaration between Macedonia and Bulgaria on 22 February 1999, Sofia expressed its unconditional support for Macedonia's European integration. The same was done by the Macedonian side and the Republic of Bulgaria started its negotiations for

1 Contact address: ratevski@gmail.com 
European membership in 2000, without Macedonia raising the issue of discrimination against the Macedonian minority in Bulgaria. Two weeks after Bulgaria received a date for the start of negotiations, on 29 February 2000, its Constitutional Court banned the only Macedonian party in Bulgaria (OMO "llinden" - PIRIN), registered only a year before (in the same month in which Bulgaria submitted its application for a date for the start of negotiations). Despite its constitutional obligation to care for the status and rights of persons belonging to the Macedonian people in neighbouring countries, and despite the continuous discrimination against the members of the Macedonian minority in Bulgaria and their organizations - which in 2001-2006 resulted with the first five judgments ruled by the European Court of Human Rights (ECtHR) in Strasbourg where multiple violations of Article 11 of the European Convention on Human Rights were attributed to the Bulgarian authorities - the Republic of Macedonia chose not to react, thus Republic of Bulgaria grasped the opportunity to successfully start and complete the European integration process. Understandable in this period, Sofia did not make any provocations and promised full support for Macedonia's future European integration. That changed in June 2006 when it became de facto clear that the Republic of Bulgaria would become a EU member-state as of 1 January 2007. The concrete occasion for the change of its position was the attempt of 5700 Bulgarian citizens to re-register $0 \mathrm{MO}$ "Ilinden"-PIRIN after ECtHR previously condemning deregistration of the party (Decision № 59489/00 of 20/10/2005, final on 20/01/2006). The legitimate and democratic attempt of the citizens of the Republic of Bulgaria to (re)establish their own party in Bulgaria was interpreted by the Bulgarian government as a provocation incited by the Republic of Macedonia. Bulgarian support turned to be "conditioned" by a prior fulfilment of several prerequisites, such as one stipulating "principles of good neighbourliness", which Bulgaria understood as "the absence of aggression towards the Bulgarian nation and history by the Macedonian authorities" (Makedonia, 2006; Macedonism, 2006). This line has escalated to be realized in recent years in serial key documents.

In the Treaty of Friendship between the Republic of Bulgaria and the Republic of Macedonia from 1 August 2017, in Article p. 11.5 at the insistence of the Bulgarian side, a very rare for the international diplomatic practice asymmetric one-sided obligation (Kirilova, 2020) was inserted: "The Republic of Macedonia hereby confirms that nothing in its Constitution may be and should be interpreted in a way that it constitutes or shall ever constitute the basis for interference in the internal affairs of the Republic of Bulgaria, with the purpose of protecting the status and rights of persons, who are not nationals of the Republic of Macedonia" (Treaty, 2017). This text is directed against the Macedonian minority in Bulgaria, as it will be repeatedly expressed by the Bulgarian side in the coming years. ${ }^{2}$

In its Framework position regarding the enlargement of the EU in relation to Macedonia and Albania from 09.10.2019, the Bulgarian government directly stated that: "The Republic of Northern Macedonia should suspend and refrain from pursuing a policy, in whatever form, of supporting and

2 For example, this is directly stated in the Clarification Memorandum that Bulgaria submitted to the EU members: "The Treaty also confirmed that any claims to the existence of the so-called 'Macedonian minority' on the territory of Bulgaria were unfounded" (Memorandum 2020, also: Framework position, 2019). 
promoting claims for recognition of the so-called 'Macedonian minority' in Bulgaria." (Framework position 2019). It was supported by the parliament with a special declaration on the same day (Declaration, 2019)

In Bulgarian Clarification Memorandum to the EU members from September 2020, a large part contains the request to the Republic of Macedonia to accept that the Macedonian minority in Bulgaria does not exist and to not support in any way the actions of the Bulgarian citizens with Macedonian self-awareness. It contains a whole section entitled "Minority Claims", in which Bulgaria states that with Article 11 of the Treaty for friendship Macedonia "agreed that there are no objective historical or demographic grounds for seeking minority status for any group of citizens in Bulgaria". There the very idea that there is a Macedonian minority in Bulgaria is considered as hate speech, hostile propaganda and the creation of stereotypes: "Official textbooks on history and geography, literature, visual arts, as well as some media, have also been used to reinforce these claims and to create antagonism with Bulgaria by spreading stereotypes... These manifestations of state-funded anti-Bulgarian ideology and practice contradict European values and should not be legitimized by joining the EU" (Memorandum, 2020).

From Bulgarian perspective, not only p. 5 in Art. 11 of the Treaty, but also the other parts of Article 11 are directly or indirectly aiming at preventing any kind of support of the Macedonian minority and its organizations: not encouraging or supporting "actions directed against the other country, which have a hostile character" (1), not allowing their territories to be used by organizations and groups with separatist goals and other hostile activities (2); no territorial claims (3) can only protect the rights of its citizens on the territory of the other country (4); will take measures to prevent malicious propaganda by institutions and "will discourage the activities of private entities, aimed at inciting violence, hatred or other similar actions, which would harm their relations" (Treaty, 2017).

In all these demands, in one way or another, the Bulgarian positions towards the Macedonian minority are represented: this is a non-existent minority, the activities of its members are incited and supported from other states, and they have anti-Bulgarian, hostile and separatist character (regardless of the fact that the authorities never managed to offer any evidence in support of any of these claims). ${ }^{3}$

Regardless of the fact that on 18 November 2020, Macedonian Prime Minister Zoran Zaev declared that Macedonia has no minority and territorial claims against Bulgaria (Zaev, 2020), Bulgaria still blocked Macedonia EU candidacy in December 2020.

\section{Bulgaria and its problems with the Macedonian minority}

These positions of Bulgaria directly contradict two indisputable facts:

3 Compare the comment in the Advisory Committee's latest report: "the authorities have not informed the Advisory Committee of any action of the above-mentioned associations or their members during the monitoring period which might have compromised the territorial integrity or unity of the Bulgarian state" (Advisory 2020 \& 99). 


\section{Seculurity}

1. The Macedonian minority in the period 1946 - 1963 was officially recognized in Bulgaria and enjoyed certain cultural rights such as the study of the Macedonian language and history (1947/8) or of the History of the Macedonian revolutionary movement (until 1964), certain opportunities for the development of folklore and the like (Frusetta, 2006, pp. 296 - 302).

2. $\mathrm{n}$ all censuses in the Republic of Bulgaria in the last 80 years, thousands of citizens in Bulgaria identified themselves as Macedonians.

At the time when the Macedonian minority was recognized, a high number of Macedonians were registered in the censuses, especially in the Blagoevgrad Province, historically known as Pirin Macedonia. Thus, on the school census for the academic year 1946/1947 out of a total of 43,920 students in the field, 35,184 (77.51\%) identified themselves as Macedonians, 4538 (10.33\%) as Macedonian Muslims, 3184 (7.25\%) as Bulgarians, and 1014 (2.31) \% as Roma, Turks, Jews, etc. (Jotevski, 1996, pp. 109 -111). In the 1946 state census, 169,544 people in Bulgaria identified themselves as Macedonians, mainly in Pirin Macedonia. Especially important is the 1956 census, organised with special measures to ensure free self-determination of Macedonians in Pirin Macedonia (Stojkov, 2015/2016, p. 73 n. 31). There 178000 people declared themselves as Macedonians in Pirin Macedonia, where they occur as $63.33 \%$ of the population (versus $33 \%$ Bulgarians), and 187787 in whole Bulgaria (Kanev, 1998, p. 97),

After the change of policy towards the Macedonian minority in 1963, during 1964 - 1965 mass agitation was undertaken to change the ethnicity of the population during the issuance of the new ID cards and the authorities managed to register $85 \%$ of the population in Pirin Macedonia as Bulgarians, but despite all measures, $30000(11 \%)$ still managed to register as Macedonians (Marinov, 2013, p. 154). The 1965 census organized after a big campaign of intimidation and using manipulation ("one manoeuvre" according to the dictator T. Zhivkov - Marinov, 2013, p. 154) reduced the numbers of Macedonians in Pirin Macedonia to 1437 or $0.4 \%$ of the population (in accordance with the communist practice to leave up to $1 \%$ "others" to demonstrate "freedom"); however, in the interior of Bulgaria where manipulation was more difficult to carry out due to the scattering of Macedonians, they kept the former number of 8230 (Jotevski, 1996, p. 154; Marinov, 2013, 156 ). At the 1975 census "citizens of non-Bulgarian origin" including Macedonians were observed, but the results were never published (Marinov, 2013, p. 155). In all censuses between 1963 - 1989, intimidations, tortures and manipulations were used to reduce the number of Macedonians (see below for repressions).

The results of the censuses after the fall of communism show respectively - 10803 (1992), 5 071 (2001) and 1608 (2011) Macedonians. During those censuses, campaigns were conducted to intimidate Macedonians through the media and public investigations against Macedonian activists were launched. In connection with the 2010 pilot census, 5 senior officials at the National Statistical Institute were fired for allowing a column with "non-existent ethnicities" (an option appeared on the electronic census under the column of "others" to check "Macedonians") The results of the 2011 census regarding minorities were rejected by the Statistical Institute itself as inaccurate due to the existence of about 730000 people without indicated ethnicity on the 


\section{Seceururity}

census, mainly from minorities (Doklad, 2011; Advisory 2020). Despite the results, "Macedonians are not mentioned in the overview published by the National Council for Co-operation on Ethnic and Integration Issues but figures on persons identifying as Macedonians were published in the 1992, 2001 and 2011 census results" (Advisory 2020, \& 23).

The Bulgarian politics of denial of the very existence of the Macedonian minority was formulated in the secret plenum of the Central Committee of the Bulgarian Communistic party in March 1963, in which Todor Zhivkov delivered a special speech, in which he stated, among other things, that: "The population of the Pirin region is part of the Bulgarian nation. There is no Macedonian ethnicity there and there cannot be ... that population can in no way be considered part of the Macedonian nation, which is being formed now in Vardar Macedonia and non in the least it can be said to ever join that nation ... It is necessary to actively, continuously strengthen the Bulgarian ethnic consciousness in that population" (BKP, 1999, p. 1288, 1292, 1203).

As a consequence, the Macedonian minority in Bulgaria became an object of active repressions and prosecutions. Many measures were taken for assimilation and change of the ethnicity of Macedonians, which led to mass persecution and sending hundreds of people to prisons, in internment, even more lost school or work, or were prosecuted in other ways. The policy of creating a homogenous Bulgarian socialist nation started with the denial and assimilation of Macedonians - the first "revival process" and the only one that was never condemned in Bulgaria, has given a large number of victims, a small percentage of which is documented (Gruev, 2011; Stoykov, 2013) but even this small percentage in the period 1956 - 1975 alone refers to over 85 people, who are estimated to be only about $30 \%$ of the sentenced to jail for their Macedonian views in these years (Stoykov, 2020, $205-255)$.

In the period $1973-1983$, between 23 - 47\% of the capacity of The third department of the 6 th Directorate of Security Services (specialized in the fight against minority nationalism) was allocated to fight the Macedonian minority ("pro-Macedonian nationalism"), even competing with the efforts against the far larger Turkish minority (Stojkov, 2020, p. 237, 238).

Bulgaria has not changed its policy towards the Macedonian minority after the fall of Communism in 1989, with the exception that Macedonians are not sent to prison for expressing their ethnicity. Until 2007 all peaceful gatherings of Macedonians were forbidden and dispersed, and to this day attempts of registration of their own NGO's are prevented leading to 14 verdicts against Bulgaria in Strasburg. ${ }^{4}$

4 European Court of Human Rights (ECtHR) Boris Stankov and United Macedonian Organisation "llinden" v. Bulgaria no. 59491/00. Judgment of 19 January 2001; ECtHR, United Macedonian Organisation Ilinden - Pirin and others, no 59489/00 Judgment of 20/10/2005, final on 20/01/2006; ECtHR, Ivanov and Others v. Bulgaria, no. 46336/99, 24 November 2005; ECtHR, United Macedonian Organisation Ilinden and others, 59491/00, Judgment of 19/01/2006, final on 19/04/2006; ECtHR, United Macedonian Organisation "llinden" and others v. Bulgaria no. 34960/04. Judgment of 18 October 2011; ECtHR, United Macedonian Organisation "llinden" and Ivanov v. Bulgaria no. 37586/04. Judgment of 18 October 2011; ECtHR, Singartiyski and Others v. Bulgaria no. 48284/07. Judgment of 18 October 2011; ECtHR, United Macedonian Organisation Ilinden - PIRIN and Others v. Bulgaria. No. 2 nos. 41561/07 and 20972/08 Judgment of 18 October 2011; Kiril Ivanov v. Bulgaria (Application no. 17599/07); Yordan Ivanov and Others v. Bulgaria (Application no. 70502/13); United Macedonian Organisation Ilinden and Others v. Bulgaria (No. 3), (Application no. 29496/160); Vasilev and Society of the Repressed Macedonians in Bulgaria Victims of the Communist Terror v. Bulgaria, Judgment of 28 May 
Immediately after the fall of Communism - on 6 March 1990, this political line against the minority was reinforced by the Bulgarian Parliament in respond to Yugoslavia's request for recognition of the Macedonian minority with a declaration describing the request as an attempt to interfere in Bulgaria's internal affairs and "distort our national history" and declaring that "there is no historical or legal, nor any other grounds for seeking such a minority", and called it "a non-existent minority" (Rabotnichesko delo, 1990, p. 1). It has remained the permanent position of the Bulgarian government so far. On 29 February 2000 it becomes part of the decision of the Constitutional Court of the Republic of Bulgaria: "In the Republic of Bulgaria there is no separate Macedonian ethnos" (Hadzistoychev, 2000). This statement will become the basis of a series of court decisions rejecting the requests of Macedonians in Bulgaria to register their organizations (See for example: Uzunova, 2014a; Uzunova, 2014b; Petkov, 2015a; Petkov, 2015b; Tsolova, 2019; Uzunova, 2020; Dimitrov, 2020; Ivanov, 2020, 2; Nicolova, 2020, 2), or serve as an argument for revoking the registrations of such (Gulubova, 2019). In these court decisions the very claim that there is such a minority is treated as an anti-state, anti-constitutional activity directed against the unity of the nation, the territorial integrity of the country, and even the rights of the majority of citizens. As an illustration, I will cite the argumentation in three such court decisions:

"In the Republic of Bulgaria there is no formed Macedonian ethnos and part of the indicated in the Association statute claim that such ethnos exists, as a minority, without rights and are calling for its endurance and protection of the Macedonian cause, because of which they represent actions against the unity of the Bulgarian nation and its territorial integrity including as a basic constitutional principle in the sense of article 44, 2 of the Constitution" (Ivanov, 2009).

"The registration is inadmissible ... because the activity of the registrant structure will affect the unity of the Bulgarian nation.... the means to achieve its goals ... The way they are formulated, the sense in which they are used, and the invested content reveals their political character imposing the ignoring of the Bulgarian character of certain geographic regions. So... activities are foreseen, connected to the Macedonian past and heritage, organizing lectures, speeches and reports about past and present problems of the Macedonian people, they proclaim collection, publishing and conservation of memoirs and other materials related to the "repressed Macedonians in Bulgaria" and also providing juridical and other assistance of activities of the "repressed Macedonians." ... All these lead to the conclusion that it is a claim for the registration of an association the goals and name of which are against the law. It cannot be admitted that it is the case of a structure with goals to protect the historical traditions and cultural wealth of a certain community....

The realisation of the essential goals undoubtedly will negatively reflect on the unity of the Bulgarian nation and its sovereignty." (Blagoevgrad, 2010).

"The Constitutional norm of art. 44, par. 2, prohibits organizations whose activities are directed against the sovereignty, the territorial integrity of the country and the unity of the nation, towards encouraging racial, national, ethnic and religious hatred, towards the violation of the rights and freedoms of the citizens. As such follows to be qualified also the organization for the protection of the interests of an ethnic minority which is not historically structured and formed on the territory of the Republic of Bulgaria... The systematic interpretation of such formulated goals in the

2020 (Application no. 23702/15); Macedonian Club for Ethnic Tolerance in Bulgaria and Radonov v. Bulgaria, Judgment of 28 May 2020 (Application no. 67197/13) 
statute and the means for their achievement indicates that it contains claims for the existence of a Macedonian ethnic minority whose rights are violated and are subject to protection by the association. There is no Macedonian ethnic minority in the Republic of Bulgaria ... That is why the designation of such minority through non-profit organization-association, made to function to satisfy their specific needs, in reality it does not protect their rights, if they are no different from those of the other citizens but cultivate a different ethnic identity among a certain part of the Bulgarian citizens, identity which was not formed in a natural historical way and therefore is aimed against the unity of the nation, which is not allowed according to art. 44, par. 2 of the Constitution." (Bozhkova, 2013).

Some verdicts include humiliating statements that the goals such as promotion of Macedonian folklore and history or defending the rights of Macedonian minority "are not in keeping with the norms established by Article 38 of ZYULNTS" (Maseva, 2018, pp 2-3. Decision, 2018) i.e., they are not in the scope of generally humane, humanitarian, cultural and socially useful goals.

The denial of the very existence of the Macedonian minority is the main basis for the rejections for registration of Macedonian NGOs, even though courts often use euphemisms to express this (Kanev, 2016, \& 16; Kanev, 2017, p. 2). In the courts, Macedonians are registered in documents as Bulgarians even when they clearly state that they are Macedonians, and some judges argue with them that there is no such thing as Macedonians. ${ }^{5}$

As a result, registered Macedonian organizations are short-living exceptions, and in reality, Macedonians are isolated form political and social life. Not one of the registered parties in Bulgaria defends the rights of Macedonians in Bulgaria. The two Macedonian parties in Bulgaria - OMO "llinden" - PIRIN (1997 - 2021) and OMO PIRIN (2002 - 2005) have received 4 rejections, and in the meantime the conditions for registration were raised 100 times: from 50 members in 1998 to 5000 members in 2005 (the number 5000 coincided with the number of registered Macedonians at the 2001 census - 5071), to be reduced in 2008 to 2500. The only registered party of Macedonians existed for one year. There were dozens of rejected attempts for registrations of Macedonian $\mathrm{NGOs}$ in the last 30 years. Only two were registered in 2019 under strong international pressure, one of which was banned the following year and the other is in the process of being revoked.

\section{Macedonian minority issue in the Bulgarian-Macedonian relations}

The R. Macedonia, contrary to Bulgarian complaints, has not formally raised the issue of the Macedonian minority with Bulgarian governments in the last 30 years; it has not taken any official international initiatives in that direction, nor has it appeared in the role of a representative and lawyer of Macedonian organizations in Bulgaria before the ECtHR (something Bulgaria regularly does for the organizations of the Bulgarian minority in the Republic of Macedonia). The initiatives or cases concerning the Macedonian minority in international institutions are not started by R. Macedonia, and even when some Macedonian representatives in such institutions have

5 Filchev, 2018, p. 1, 2; Manoleva, 2019, p. 1; See" "Judge Filchev declared that there are no Macedonians, all that is an invention of the Comintern, what sort of Macedonian are you, are you crazy?" (Written explanation by Tilev, 2018b, p. 4, 8; Tilev, 2018a, p. 2; Report, 2019) 
given support to some initiatives, it is not done constantly and clearly does not constitute any consistent policy of the Macedonian governments. However, the Republic of Bulgaria insists on obtaining guarantees that no Macedonian official representative in any international institution will ever support the appeals of the Macedonian minority: "The Republic of North Macedonia shall unreservedly and urgently bring its positions and actions in international organizations and formats into line with Article 11 of the Neighbourhood Treaty, clearly stating that there are no... grounds to seek minority status for any group of citizens on the territory of the Republic of Bulgaria. The multilateral formats and monitoring mechanisms of the Council of Europe should not be instrumentalized by the Republic of North Macedonia to put pressure on Bulgaria on issues related to the rights of persons belonging to minority groups" (Framework Position, 2019).

The same statement could be found in the Memorandum: "In violation of Art. 11 of the Treaty, Skopje has not changed the policy of the former governments to encourage and support individuals and organizations seeking the recognition of a non-existent 'Macedonian minority' in Bulgaria... Bulgaria expects the Republic of North Macedonia to fulfil its commitments, to suspend the above policies, to bring its positions and actions in international organizations and forums in accordance with Art. 11 of the Treaty and to end its practice of instrumentalizing multilateral formats and monitoring mechanisms for exerting undue pressure on Bulgaria. This will be a prerequisite for obtaining Bulgaria's consent for each next step in the integration process" (Memorandum, 2020).

The goal of the Bulgarian government, however, is not only to guarantee that the appeals of the Bulgarian citizens with Macedonian ethnic identity in the future will not receive support from the Republic of Macedonia as an EU member, but also as we saw in Art. 11 of the Treaty, to prevent any support on an individual level that citizens of the Republic of Macedonia could give to their co-ethnics in Bulgaria based on a sense of national solidarity.

Initiatives for the protection of the rights of the Macedonian minority are developed on the initiative and in the organization of Bulgarian citizens with Macedonian self-awareness, and with the support of international institutions and organizations, as well as some Bulgarian organizations such as the Bulgarian Helsinki Committee. The pressure on Bulgaria comes from the Parliamentary Assembly of the Council of Europe $(\mathrm{CoE})$, the Committee of Ministers of the $\mathrm{CoE}$, the CoE's Commissioner for Human Rights, the European Commission against Racism and Intolerance (ECRI), the Advisory Committee on the Framework Convention for the Protection of National Minorities (FCNM), the independent human rights observers at the UN, The Rule of Law Monitoring Committee (DRFMG) in the European Parliament, the European Free Alliance and the European Parliament. All of them in their reports on Bulgaria in recent years have raised the issue of the rights of the Macedonian minority members. The Committee of Ministers $(\mathrm{CoE})$ has placed Bulgaria under intensified monitoring since 2016 for not executing the judgments delivered in these Macedonian cases. With the last two ECtHR's decisions from May 2020, the judgments against Bulgaria for violating the rights of Macedonians in Bulgaria became 14. In 2020, a series of international institutions raised the issue of the Macedonian minority to the Bulgarian government. On 10 March 2020, the Commissioner for Human Rights highly recommended the following: 
"Bulgaria should take decisive measures to execute the Court's judgments concerning the right to freedom of association of persons aiming to advance the recognition of the Macedonian minority in Bulgaria and the promotion of Macedonian culture. The authorities are urged to allow persons identifying as ethnic Macedonians to register their associations and refrain from refusing registration on grounds related to the recognition or non-recognition of the Macedonian minority in Bulgaria ... to engage in a constructive dialogue with persons identifying themselves as ethnic Macedonians" (Report, 2020, \& 49).

On 26 May 2020, the Advisory Committee on the FCNM adopted its 4th report for Bulgaria and concluded, "the authorities have not entered into a dialogue with persons identifying as Macedonians, who continue to request recognition as a national minority and protection under the Framework Convention" (Advisory, 2020, \& 13). DRFMG on 28 August 2020, in its 23rd question to the Bulgarian Minister of Justice and the Commission against Discrimination, asked what measures would be taken in relation to, among other things, "attempts to hinder the work of e.g., NGOs working with the Macedonian-Bulgarian minority (deregistering and NCO)" (DRFMG, 2020). On October 1, the CoE's Committee of Ministers in its resolution directly asked Bulgaria to stop discriminating organizations fighting for the recognition of the Macedonian minority in Bulgaria (Resolution CM, 2020). On 2 October 2020, The European Parliament adopted a resolution on Bulgaria in which it demanded from the Bulgarian Government: "to take all necessary measures to safeguard the rights of minorities effectively, in particular the rights to freedom of expression and freedom of association, including through the implementation of the relevant judgments of the European Court of Human Rights" and in footnote cited the ECtHR judgments for Macedonian NGO OMO "Ilinden" (EP Resolution, 2020, 15, n. 3).

As we can see, these are not only institutions in the framework of the Council of Europe in Strasburg or UN, but also of the European Union where R. Macedonia is not a member. The reactions in Bulgaria to this pressure are extremely negative.

The accusations against the Republic of Macedonia are therefore on one hand baseless because even if R. Macedonia really implemented the politics of supporting the Macedonian minority in Strasbourg - it is not something negative or in any way directed against Bulgaria; on the other hand, it is simply not true. Bulgarian positions on this matter are not based on real facts, but on the ideological need to explain the existence of people with Macedonian self-awareness in Bulgaria and their actions without recognizing the minority. If such minority does not exist, it means that someone from outside is creating problems. "The problem with the creation of a Macedonian minority started from outside... This is not a process initiated by internal forces in Bulgaria" (Prodanov, 2020) and accordingly the "provoked from outside demands for minority are unacceptable" (Memorandum, 2020). Bulgaria categorically refuses to accept the reality that the activities are on the one hand - the work of its own citizens, and on the other hand that they are not directed against the state, nor against its institutions and integrity ${ }^{6}$ but only in the direction of the affirmation of minority rights under international law.

6 The striving of the Macedonian minority organizations towards registration is by itself a clear sign that they recognize the state laws and institutions and that they want to work within their framework. 


\section{Seculurity}

\section{The roots of this anti-minority policy}

All conditions raised by Bulgaria to the R. Macedonia about history, language and minority evolved together as part of the evolution of Bulgarian policy about the Macedonian minority. In the period 1946 - 1948, when Bulgaria was ready to exchange Pirin Macedonia for other territories in Yugoslavia and become a part of the future enlarged South Slavic federation, the Bulgarian authority and science were ready to recognize the existence of a Macedonian identity even in the Middle Ages (Angelov, 1947, 1 - 15; Jotevski, 1996, pp. 125, 126). After the eruption of the Stalin - Tito conflict in 1948, the Bulgarian government saw a chance to turn this policy around and to use Macedonian minority as a tool to expand its territory, by proclaiming a policy for the unification of Macedonia but within Bulgaria and Pirin Macedonia to serve as a Piedmont (Marinov, 2013, p. 51). For the implementation of this policy a redefinition of the Macedonian nation and its history was made in the way to give arguments for this new line. According to the new official version, the Macedonians were part of Bulgarian people until 1878, and then gradually separated into a separate nation but still closest to Bulgarians, and learning the Macedonian language was stopped as "not wanted" by the population that already used Bulgarian language in the past. At the same time, Sofia had to deflect Yugoslavia's and Macedonia's aspirations for Pirin Macedonia, supported by the self-determination of the majority of the population there according to the censuses results, where Macedonians appeared closely to 2/3 of the total population in the province. To counter this, Sofia post-factum declared the results of the 1946 census as exaggerated and not proper expression of self-determination of the population. According to the new official line, there were Macedonians in Bulgaria, but they were a minority even in Pirin Macedonia. This policy of 'unified Macedonia within Bulgaria' came to an end in 1956 with the normalisation of the relation between Moscow and Belgrade. Simultaneously, the census of 1956, when $63 \%$ of the population in Pirin Macedonia self-determined itself again as Macedonians, left the Bulgarian state without arguments against renewed in 1957 Yugoslavian claims for the autonomy of Pirin Macedonia.

This led to a new change of the Bulgarian position with a simple goal to avoid the danger of losing territory, which in the period 1957 - 1963 evolved into the conclusion that the only permanent and safe solution was removing the self-awareness of the problematic minority. These led to a change in the interpretation of the Macedonian nation itself. The next version of history was accepted by the political leadership, namely, the same version of history that Bulgaria wants to impose on Macedonia today. The historiography and philology were mobilised (Stojkov, 2015/2016, pp. 71 - 81) to prove that the Macedonian minority in Bulgaria could not exist because the Macedonian nation was formed only after 1944 and only in the Republic of Macedonia, and the history, culture and language of Macedonians were and are Bulgarian (Stojkov, 2020, pp. 231 - 238). The only reason for the change of date of the "creation" of the Macedonian nation from 1878 to 1944 was to annul any possibility that the people in Pirin Macedonia were part of the process of the creation of the Macedonian nation. Even today, the so-called liberal wing in Bulgarian historiography does not deviate from this red line - the Macedonian nation could not have started to form before 1912, not because it is a fact or that there are no documents to 
the contrary (there are many), but because if the beginning of the process was before dividing Macedonia, it also could mean that it included Pirin Macedonia.

The official position on censuses results also evolved. If in the period 1948 - 1956 it was claimed that they were only exaggerated, but still partially real, after 1956 they were completely denied and "explained" by alleged violence - and the whole process was labelled "violent Macedonianization" (for example: Angelov, 2004). To this date, no specific individual case of a person repressed for refusing to declare himself as a Macedonian has been documented, unlike the well-documented repression of members of the Macedonian minority. Against the results of the censuses after 1956 when the thesis of "violent Macedonianization" is not an applicable explanation, the Bulgarian state adopted a position that even if there were some individuals who identify themselves as Macedonians, they were not objectively different from other Bulgarian citizens and therefore they do not constitute a national minority. Liberal Bulgarian scientists today also cannot cross this red line - to recognize that the thousands of people who identify themselves as Macedonians in the censuses constitute a minority, a collective; for them, they are individuals who do not constitute a collectivity and cannot be viewed as a minority. In that, all the wings of the Bulgarian intelligentsia are in consensus - the Macedonian minority does not exist and cannot exist, and the Macedonian nation should be formed only inside the borders of Republic of Macedonia.

The reality that the historical dispute has as one of the key goals to create a narrative that excludes the possibility of the existence of the Macedonian minority in Bulgaria is very directly stated in the Explanatory Memorandum of the Bulgarian government:
"The process of identity building was limited only to the territory of the former Socialistic Republic of Macedonia, and after 1991 to the Republic of Macedonia. Although Bulgarian citizens did not take part in it, the authorities in the Republic of North Macedonia still claim that there is a 'Macedonian minority' in Bulgaria.... However, Bulgaria cannot accept that the ongoing process of nation-building in the Republic of North Macedonia will be realised through... unsubstantiated allegations of the existence of a 'Macedonian minority' in Bulgaria" (Memorandum, 2020). "The Republic of North Macedonia ... (should) ... clearly declare that there are no historical and demo- graphic grounds to seek minority status for any group of citizens on the territory of the Republic of Bulgaria" (Framework Position, 2019).?

Similarly, the issue of the Macedonian language is closely intertwined with the aspiration to deny any possibility of the existence of a Macedonian minority in Bulgaria. The Macedonian language was already taught in the schools in Pirin Macedonia in 1948 and was used on the Bulgarian national radio. The policy for its denial gradually escalated in parallel with the attempts to manage the "problem" with the Macedonian minority, started in 1948 with the criticism of the Macedonian literary language as being allegedly "artificial" and even "Serbianized", but without

\footnotetext{
7 The same ideologically driven motivation explains the great efforts that the Bulgarian state is making to artificially create Bulgarian minorities in Albania and Kosovo by granting Bulgarian citizenship and blackmailing the Albanian government on its path to European integration - the aim is to show that the Macedonian nation and identity exist in the middle of the "Bulgarian ethnic space" and that the process of the formation of the Macedonian nation does not extend beyond the Republic of Macedonia, despite the reality that there are Macedonian minorities in Greece, Albania, Kosovo and Bulgaria.
} 
offering an alternative, and then with the position that the Bulgarian language appears close and even native to the Macedonian minority in Bulgaria, to reach an open denial of the uniqueness of the Macedonian language in 1960s and insisting that it is part of the Bulgarian language and could not be more than a regional written norm of the Bulgarian language. For this purpose, a purge was made among Bulgarian scientists who recognized the Macedonian language, some like Professor Dina Stanisheva lost their jobs, and others, like a Bulgarian Academy of Science's member Ivan Lekov, were retired prematurely. This position has been strictly maintained to this day. ${ }^{8}$ The language question is closely linked not only to the questioning of the Macedonian identity in general, but also to the denial of the Macedonian minority. If Macedonian was recognized by Bulgaria as a separate language, it would not only be viewed as a recognition of a separate ethnic basis of the Macedonian nation, but also as an objective criterion for the recognition of the Macedonian minority in Bulgaria, whose members would have the right to seek to study the language of their nation. ${ }^{9}$ Insisting that it is a Bulgarian dialect or a Bulgarian regional norm takes away such an "objective basis" for the existence or recognition of the Macedonian minority.

Thus, the three questions raised by Bulgaria to Macedonia - about language, history and the minority (the primary issue being the issue of the minority), are essentially three aspects of the same problem - an attempt to ideologically redefine reality to defend the Bulgarian national myth and take away any basis for the recognition of the Macedonian minority. ${ }^{10}$ The real goal of the Bulgarian policy is perfectly summarized in the statement on 31.102020 given to Reuters by the Bulgarian foreign minister:

"The Bulgarian pressures are related to the constant claims of the Republic of North Macedonia for the Macedonian minority in our country", and as a way to avoid the Bulgarian veto, she "see the possibility of Skopje recognizing that their roots and language had a Bulgarian basis and thus to put an end to all claims that there is a clearly expressed 'Macedonian' minority. If North Macedonia agrees, Sofia is ready to recognize Macedonian as one of the official languages of its neighbour, as well as Macedonian identity." (Zaharieva, 2020).

Unable to convince Macedonians in Bulgaria to stop fighting for their rights, Bulgaria rejects the dialogue with them and prefers to negotiate for its own citizens with a foreign country.

The Bulgarian authorities understand the European integration of Macedonia and the possibility of it being blocked by Sofia as the only and last chance to force Skopje to accept Bulgarian claims, something that has not succeeded so far, and there are no prospects of it to be achieved. The right for veto is turned into a simple blackmail. Created by a totalitarian regime, Bulgarian

\footnotetext{
8 See: "the official language used in today's Republic of North Macedonia can only be considered as a written regional norm of the Bulgarian language" (Memorandum, 2020).

9 As Bulgarian government openly admitted about Macedonian language "Today, regional versions of the same language are still spoken on both sides of the border between Bulgaria and the Republic of North Macedonia." (Memorandum, 2020)

10 Compare in Memorandum, 2020: "Reconsideration of our common history, denial of our common ethnic and linguistic roots or unfounded claims about the existence of a 'Macedonian minority' in Bulgaria ... unfounded minority, historical, linguistic and other claims", those three are put together in every sentence.
} 


\section{Seceururity}

policies endanger not only the minority rights but equally the rights to free expressions and freedom of science, and European integration processes.

\section{Bulgarian argumentation against the demands from its own citizens and international institutions}

The Bulgarian policy aims to isolate the Macedonian minority from political and social life, and to cripple it capacity to defend its rights and cultivate, preserve, and transmit its culture and self-awareness, giving opportunity to the state policy of assimilation to finish its job. Many Bulgarian politicians and nationalists often express their hopes and believe that time is working in their favour and against the survival of the Macedonian minority.

Simultaneously, Bulgaria tends to block every foreign intervention in favour of the Macedonian minority, not only from R. Macedonia, but most importantly from international institutions. The outside pressure and external interference are viewed as serious danger that could hinder the policy of assimilation of the minority. International pressure is offset by three different levels of argumentation.

Firstly, the absence of a generally accepted and legally binding definition of a term "national minority" is interpreted by the Bulgarian authorities as a justification for refusing to define whether there are such minorities in Bulgaria. Even though the Framework Convention has been ratified in Bulgaria, it is still quite common for representatives of the Bulgarian government to declare that there are no minorities in Bulgaria, and especially not a Macedonian minority. ${ }^{11}$

Secondly, based on the fact that international law predominantly guarantees individual rather than collective rights, Bulgarian authorities oppose to prescribe strict minority rights, because "Bulgaria does not give collective, but only individual rights" (Memorandum, 2020). Minority rights, however, are individual rights, which can be exercised collectively - or "individually as well as in community with others", as stated clearly in the Art. 3. par. 2 of the FCNM - in the very same manner as other human rights (right of the freedom of assembly, organization, marriage, etc. Convention, 1995, Art. 5, para. 2).

Thirdly, by imposing a differentiation between objective and subjective criteria for the recognition of a minority.

"The right to free individual self-identification is inextricably linked to the objective criteria related to the identity of the person. Therefore, on the basis of the Constitution of the Republic of Bulgaria, this right can be exercised according to the cumulative fulfilment of both subjective (presence of free will to belong to a certain ethnic, religious, linguistic minority group or community) and objective criteria (existence of real differences that objectively prove the existence of ethnicity, religion, language, significantly different from those of the majority)." (Memorandum, 2020).

This kind of argumentation is intentionally used to declare the impossibility of the existence of a Macedonian minority (as "not different" from Bulgarians), and in essence constitutes an attempt

11 For example, foreign minister N. Mladenov in May 2010: "There is no Macedonian minority in Bulgaria. There are no minorities in our country - there are certain ethnic groups only, and we respect their human and civil rights" (Ratevski, 2010) 
of the authorities to monopolise the right to decide whether or not to recognize the existence of a minority. This insistence is in contradiction with the international regulations, as it is directly stated in the report written by the UN's Independent Expert on Minority Issues, following its thematic visit to Bulgaria:
"The question of the existence of minorities is addressed by the Human Rights Committee in its general comment No. 23 (1994) on the rights of minorities. Article 5.2 states that 'the existence of an ethnic, religious or linguistic minority in a given State party does not depend upon a decision by that State party but requires to be established by objective criteria'... the Committee on the Elimination of Racial Discrimination has established in its general recommendation No. 8 (1990) on article 1 of the Convention that 'such identification shall, if no justification exists to the con- trary, be based upon self-identification by the individual concerned"' (Report, 2011, \& 94, 95).

Much in the same line are the observations made by the Advisory Committee on the FCNM, stipulated in the $4^{\text {th }}$ opinion on Bulgaria's execution of the Convention's articles in practice:

\begin{abstract}
"the right to free self-identification contained in Article 3 of the Framework Convention is not only a central provision of the Framework Convention but, as the European Court of Human Rights has pointed out, "the 'cornerstone' of international law on the protection of minorities in general." While it may be legitimate to link the recognition of a group as a national minority to objective criteria, these criteria must not be defined or construed in such a way as to limit arbitrarily the possibility of such recognition and the views of persons belonging to the group concerned should be taken into account by the authorities when conducting their own analysis as to the fulfilment of objective criteria. While member states have a margin of appreciation in determining how to approach the question of right-holders in compliance with national and international obligations, they shall seek solutions that are not arbitrary and prevent the unjustified exclusion of persons from protection under the Framework Convention. Furthermore, the Advisory Committee recalls that recognition by the state as a minority is not a prerequisite to qualify for the protection of the Framework Convention" (Advisory 2020, \&25).
\end{abstract}

Bulgarian position did not change: Bulgaria insists on the denial of the existence of a Macedonian minority to be accepted as part of the conditions for good neighbourliness, and then for the right to determine whether or not Macedonia fulfils the conditions for good neighbourliness at each stage of Euro-integration, and urges member states to support it (Memorandum, 2020). In this, there no difference between the communistic dictator Todor Zhivkov, the today's Bulgarian nationalists, or even the liberals - they all repeat the same infamous formula: "There was never a Macedonian minority in Bulgaria, there is not and there will/cannot be" (Dzambasky, 2020; Kunev, 2020).

\title{
The last totalitarian communist policy in the EU
}

While at the time the policy of denying the existence of the Macedonian minority emerged, it had a partial excuse in the fear of possible territorial losses; nonetheless, the methods through which it was implemented and its intermediate goals left it without legitimate basis, and one might rightfully define it as a totalitarian nationalist policy directed towards assimilation and repressions. It has led to many sufferings and problems for both ethnic Macedonians in Bulgaria 
but also on the Balkans generally (Stoykov, 2013; Stojkov, 2020, pp. 205 - 255). As it is obvious, it continues to create many problems both in terms of the rights of some citizens of the Republic of Bulgaria, as well as in relations between Bulgaria and Macedonia. Today that policy is only an ideological relic of the totalitarian past - the last living totalitarian policy in the European Union. The main goal for its creation lost its significance long ago - today there is no danger of losing territories or harbouring separatist aspirations among the Macedonian minority. Namely, after some 60 years of persecution, discrimination and assimilation, persons with Macedonian ethnic identity in Bulgaria turned out to be a minority even in Pirin Macedonia, i.e., the region where the vast majority of population twice in a decade (1946-1956) declared themselves as ethnic Macedonians. The European integration process alone should make such fears also unfounded. However, the mechanisms and state structures created after the 1960s - by the communist elite, in what used to be a People's Republic of Bulgaria - and tasked to enforce that kind of policy are still alive, and the ideology created by them even nowadays shapes the minds of the political and cultural elite in Sofia. The attempts to proceed unimpededly with the policy of the former communist dictator Todor Zhivkov by abusing the instruments of European integration cannot bring anything good.

However, it hints a very serious problems ahead - Macedonia cannot do anything for the Macedonian minority in Bulgaria to disappear, nor to order the Bulgarian citizens to act 'properly'. However, Bulgaria, being trapped in the parallel universe created by its very ideology, will continue to interpret the actions of its own citizens with Macedonian self-consciousness as being purportedly inspired by Skopje - and thus as an allegedly hostile anti-Bulgarian activity of the Republic of Macedonia - which, in the end, will probably result in another blockade of Macedonia's European integration path, and in such a way will endanger the European future of the Balkans.

Therefore, the future of the Republic of Macedonia becomes a hostage to an internal problem for Bulgaria, which Sofia is unable and unwilling to solve. The vicious circle between the struggles of the Macedonian minority in Bulgaria and the irrational nationalist ideology of Sofia, incapable to accept the reality, tends to be a never-ending story. In other words, Sofia continues to fight for its totalitarian dreams, whereas ethnic Macedonians (in Bulgaria and Macedonia alike) are put in the position of being 'collective hostages' to Bulgaria's 'nightmares'.

\section{References}

1. Advisory (2020): Advisory Committee on the Framework Convention for the protection of National minorities, Fourth Opinion on Bulgaria - adopted on 26 May 2020, ACFC/ OP/IV(2020)001Final, https://rm.coe.int/4th-op-bulgaria-en/16809eb483 \& 25 (used on 21.02.2021).

2. Annual report on the human right situation of the Macedonian minority in Bulgaria and the rights of Bulgarian citizens with a Macedonian consciousness (2019). http://www. omoilindenpirin.org/news/2020/june2_e.php.

3. Angelov V. (2004). Веселин Ангелов, Хроника ан едно национално предателство. Опитите за насилствено денационализиране на Пиринска Македония (1944 - 1949), София. 
4. Angelov D. (1947). Димитър Ангелов, „Принос към народностните и поземлените отношение в Македония (Епирския деспотат) през пьрвата четвърт на XIII в.", Известия на камарата на народната култура, серия Хуманитарни науки, 6р. 4, София, 1947 г., 1 - 15.

5. ВКР (1999). БКП, Коминтернът и македонският въпрос (1917-1946), т. 2, Архивите говорят, кн. 5, София: Главно управление на архивите.

6. Blagoevgrad County Court (2010). Case № 12/2010, rejects the registration demand of the Association of Repressed Macedonians.

7. Bozhkova, (2013). Verdict № 715 of 11.04. 2013, SAS, President Svetlana Bozhkova, against Association Macedonian Club for Ethnic Tolerance.

8. БНТ, (2020). „Захариева пред Ройтерс: Притесненията ни са свързани с непрестанните претенции за македонско малцинство у нас", 31.10.2020, https://bntnews.bg/news/ zaharieva-pred-roiters-pritesneniyata-ni-sa-svarzani-s-neprestannite-pretencii-za-makedonsko-malcinstvo-u-nas-1081007news.html.

9. Convention (1995). Council of Europe, Framework Convention for the Protection of National Minorities, 1 February 1995, ETS 157.

10. Decision (2018). Decision No 20180620172319/27/6/2018 of the Agency for Registration

11. Declaration (2019). Декларация на 44-то народно събрание на Р България относно разширяване на ЕС и процеса на стабилизиране и асоцииране на Република Северна Македония и Албания, https://parliament.bg/bills/44/954-03-3.pdf.

12. Dimitrov I. (2020). Решение № 1452 от 21.07.2020 на Софийски апелативен съд, председател Иво Димитров.

13. Doklad (2011). Доклад за преброяването на населението в България 2011, http://www. omoilindenpirin.org/documents/doklad.pdf.

14. DRFMG, 2020: Democracy, Rule of Law and Fundamental Rights Monitoring Group (DRFMG): Follow-up questions to the Exchange of views on latest developments in Bulgaria in relation to Democracy, Rule of Law and Fundamental Rights held on Friday, 28 August 2020, 09.00-13.30, https://www.europarl.europa.eu/cmsdata/211284/DRFMG\%20questions\%20to\%20Bulgarian\%20authorities.pdf.

15. Dzambasky (2020). Джамбазки от ЕП: В България няма „македонско малцинство“, не е имало, няма и не може да има, https://fakti.bg/world/511020-djambazki-v-balgaria-nama-makedonsko-malcinstvo.

16. EP Resolution (2020). European Parliament resolution on the rule of law and fundamental rights in Bulgaria (2020/2793(RSP), https://www.europarl.europa.eu/doceo/ document/B-9-2020-0309_EN.html\#_ftn13.

17. Filchev I. (2018). Verdict № 2809 of 22.10 .2018 of the Regional Court at the city of Sandanski, Judge Ivan Filchev.

18. Frusetta James Walter (2006). Bulgaria's Macedonia: National-building and state-building, generalization and autonomu in Pirin Macedonia, 1903-1952 (Dissertation submitted to the Faculty of the Graduate school of the University of Maryland College.

19. Framework position, 2019: Рамкова позиция относно разширяване на ЕС и процеса на стабилизиране и асоцииране: Република Северна Македония и Албания, 09.10.2019 https://www.gov.bg/bg/prestsentar/novini/ramkova-pozitsia (used on 10.02.2021).

20. Gruev M. (2011). Михаил Груев, „Насилие, политика и памет, Комунистическият режим в Пиринска Македония - рефлексии на съвременника и изследователя", София. 
21. Gulubova (2019). Statement of claims from the Regional Prosecutor's Office in Blagoevgrad, vh No SP-3887/2019 of 21/11/2019, by the Prosecutor B. Gulubova.

22. Hadzistoychev C. (2000). Verdict № 1 from 29th February 2000 about the Constitutional Case 3 of 1999, reportning Judge Canko Hadzistoychev (Published in State newspaper № $18,07.03 .2000$ г.).

23. Ivanov I. (2009). Verdict № 407 of 07.05 .2009 by SAS, President Ivan Ivanov, regarding the registration of the Macedonian Cultural and Educational Association "Nikola Vapcarov".

24. Ivanov А. (2020). Решение № 1188 от 10.03.2020 г. на Окрьжен съд Благоевград, председател Атанас Иванов.

25. Јотевски Васил (1996). Националната афирмација на Македонците во Пиринскиот дел на Македонија 1944 - 1948 г., Скопје: ИНИ.

26. Кънев Красимир (1998). "Законодателство и политика към етническите и религиозните малцинства в България", в: А. Крьстева, (ред.), Общности и идентичности в България, София: Петекстон.

27. Kanev Krasimir (2016). Observations of the applicants, United Macedonian Organisation Ilinden and Others v. Bulgaria, ECHR, Application No. 29496/16.

28. Kanev Krassimir (2017). Brief note about Execution of the UMO Ilinden and others group of judgments Strasbourg, 24 May, online: https://staticl.squarespace.com/ static/55815c4fe4b077ee5306577f/t/592bfe6820099e2f4b159b32/1496055400986/ A+brief+note+on+UMO+llinden+v+Bulgaria+by+BHC.pdf.

29. Ралица Кирилова и Любомир Кючуков (2020). „Правителството решава вытрешни проблеми чрез спора със Скопие“, https://debati.bg/ekskluzivno-lyubomir-kyuchukov-pravitelstvoto-reshava-vatreshni-problemi-chrez-spora-sas-skopie/.

30. Кънев Радан (2020). „Няма 'македонско малцинство' в резолюцията на ЕП“, БHT, https://radankanev.eu/\%d0\%bd\%d1\%8f\%d0\%bc\%d0\%b0-\%d0\%bc\%d0\%b 0\%d0\%ba\%d0\%b5\%d0\%b4\%d0\%be\%d0\%bd\%d1\%81\%d0\%ba\%d0\%be-\%d0\%bc\%d0\%b0\%d0\%bb\%d1\%86\%d0\%b8\%d0\%bd\%d1\%81\%d1\%82\%d0\%b2\%d0\%be-\%d0\%b2$\% \mathrm{~d} 1 \% 80 \% \mathrm{~d} 0 \% \mathrm{~b} 5 \% \mathrm{~d} 0 \% \mathrm{~b} 7 \% \mathrm{~d} 0 \%$ be $\% \mathrm{~d} 0 \% \mathrm{bb} \% \mathrm{~d} 1 \% 8 \mathrm{e} \% \mathrm{~d} 1 \% 86 /$.

31. Macedonism (2006). „Льжите на македонизма“, 29 юли 2006, http://www.focus-news. net/scandal/0000/00/00/1131/.

32. Makedonia (2006). „Македония и влакът за Европа“, 25 јули, http://www.focus-news. net/hot-topic/0000/00/00/1144/.

33. Маринов Чавдар (2013). Македонското прашање од 1944 до денес, Комунизмот и национализмот на Балканот, Сорос: Скопје.

34. Memorandum (2020). „Ексклузивно: Какво пише в Меморандума на България за Северна Македония?", https://www.actualno.com/politics/ekskluzivno-kakvo-pishe-v-memoranduma-na-bylgarija-za-severna-makedonija-news_1500405.html.

35. Manoleva (2018). Verdict № 2885 of 30.10 .2018 of Regional Court at city of Sandanski, Judge Raya Manoleva.

36. Maseva (2018). Decision No 3933 of 21/8/2018 by Judge Liliya Maseva of the Blagoevgrad Regional Court.

37. Nicolova (2020). Решение № 1149, от 08.06.2020 г. на Софийски апелативен съд, председател Бистра Николова. 
38. Offnews (2020). „Заев: Нямаме претенции за македонско малцинство в България“, 19.11.2020, https://offnews.bg/dw/zaev-niamame-pretentcii-za-makedonsko-maltcinstvo-v-balgaria-740682.html.

39. Petkov (2015a). Decision No 2687 of 15/11/2015 of the Blagoevgrad Regional Court, presided over by Atanas Petkov.

40. Petkov (2015b). Decision No 2687 of 15/11/2015 of the Blagoevgrad Regional Court, presided over by Atanas Petkov.

41. Николай Проданов (2020). „Няма да чакаме ОМО „Илинден“ да ни взриви, за да я забраним",14.10.2020, http://www.class.bg/\%D0\%B1\%D1\%8A\%D0\%BB\%D0\%B3\%D0\%B0\%D1\%80\%D0\%B 8\%D1\%8F/\%D0\%BA\%D0\%BE\%D0\%BC\%D0\%B5\%D0\%BD\%D1\%82\%D0\%B0\%D1\%80\%D0\%B8/item/417812-\%D0\%BF\%D1\% 80\%D0\%BE\%D1\% 84-\%D 0\%BD\%D0\%B8\%D0\%BA\%D 0\%BE\%D0\%BB\%D0\%B0\%D0\%B9-\%D0\%BF\%D1\%80\%D0\%BE\%D0\%B4\%D0\%B0\%D0\%BD\%D0\%BE\%D0\%B2-\%D0\%BD\%D1\%8F\%D0\%BC\%D0\%B0-\%D0\%B4\%D0\%B0\%D1\%87\%D0\%B0\%D0\%BA\%D0\%B0\%D0\%BC\%D0\%B5-\%D0\%BE\%D0\%BC\%D0\%BE-\%D0\%B8\%D0\%BB\%D0\%B8\%D0\%BD\%D0\%B4\%D0\%B5\%D0\%BD\%D0\%B4\%D0\%B0-\%D0\%BD\%D0\%B8-\%D0\%B2\%D0\%B7\%D1\%80\%D0\%B8\%D0\%B2 \%D0\%B8,-\%D0\%B7\%D0\%B0-\%D0\%B4\%D0\%B0-\%D1\%8F-\%D0\%B7\%D0\%B0\%D0\%B 1\%D1\%80\%D0\%B0\%D0\%BD\%D0\%B8\%D0\%BC\#.X4mIX9AzY2x.

42. Rabotnichesko delo (1990). № 66, 07.03, София.

43. Ратевски Самуил (2010). "По следите на една престьпна политика, „Народна воля" “, юни, http://www.narodnavolja.com/articles2010/06/txt03.asp.

44. Report of the independent expert on minority issues (2011). Addendum Mission to Bulgaria. (4 to 11 July), UN A/HRC/19/56/Add. 2, https://www2.ohchr.org/english/bodies/ hrcouncil/docs/19session/A.HRC.19.56.Add.2_en.pdf.

45. Report on the situation of the Macedonian minority in Bulgaria (2013) by OMO «Ïlinden"-PIRIN, http://www.omoilindenpirin.org/news/2013/report.pdf.

46. Report of the Commissioner for Human Rights of the Council of Europe following her visit to Bulgaria on 25-29 November 2019 (2020). https://ec.europa.eu/migrant-integration/ librarydoc/report-of-the-commissioner-for-human-rights-of-the-council-of-europe-following-her-visit-to-bulgaria-on-25-29-november-2019.

47. Interim Resolution CM/ResDH(2020)197 (2020). Execution of the judgments of the European Court of Human Rights, United Macedonian Organisation Ilinden and Others group against Bulgaria, https://search.coe.int/cm/pages/result_details.aspx?Objec$\mathrm{tld}=09000016809 \mathrm{fc} 587$.

48. Стојков Стојко (2015). „Македонското малцинство во Бугарија од признавање кон негирање 1948 - 1989“, Годишен зборник на ФОН.

49. Stojko Stojkov (2020). „Persecution of 'Non-Existent': Repression of Macedonians in Bulgaria during the Communist Period (1944 - 1989)". In: Friedman Victor A., Goran Janev and George Vlahov (eds). Macedonia \& Its Questions. Berlin: Peter Lang.

50. Стойков Стойко (2013). Табу - време на страх и страдание, преследването на макеоднците в България по вреем на комунизма (1944 - 1989). Благоевград.

51. Tilev (2018a). Written explanation by Kiril Tilev from 03.10.2018.

52. Tilev (2018b). Written explanation by Kiril Tilev from 25.10. 2018. 


\section{Siabecus}

53. Treaty of Friendship, Good-neighbourliness, and Cooperation between the Republic of Macedonia and the Republic of Bulgaria (2017). Online: https://mfa.gov.mk/en/document/1712.

54. Tsolova (2019). Decision № № 2333 of 24 October 2019 to the Sofia Appellate Court, presided over by Lyudmila Tsolova.

55. Uzunova (2014a). Decision № 2768 of 30.06 .2014 by Nadia Uzunova, Regional Court of Blagoevgrad regarding the application for the registration of OMO "llinden".

56. Uzunova (2014b). Court decision No 4022 of 26.09 .2014 by Judge Nadia Uzunova, Regional Court-Blagoevgrad.

57. Uzunova (2020). Решение № 2561 от 12.06.2020, Окръжен съд Благоевград, съдия Надя Узунова. 